\title{
Nutrient utilization, ruminal fermentation, microbial abundances, and milk yield and composition in dairy goats fed diets including tomato and cucumber waste fruits
}

\author{
M. Romero-Huelva, E. Ramos-Morales, and E. Molina-Alcaide ${ }^{1}$ \\ Estación Experimental del Zaidín (CSIC), Profesor Albareda 1, 18008 Granada, Spain
}

\begin{abstract}
The effects of replacing $35 \%$ of cereals-based concentrate with feed blocks (FB) containing waste fruits of tomato, cucumber, or barley grain in diets for lactating goats on nutrient utilization, ruminal fermentation, microbial $\mathrm{N}$ flow to the duodenum, milk yield and quality, methane emissions, and abundances of total bacteria and methanogens were studied. Eight Murciano-Granadina goats $(39.4 \pm 5.39 \mathrm{~kg}$ of body weight, mean \pm $\mathrm{SD})$ in the middle of the third lactation were used and 4 diets were studied in a replicated $4 \times 4$ Latin square experimental design. Diets consisted of alfalfa hay (A) plus concentrate $(\mathrm{C})$ in a 1:1 ratio (diet $\mathrm{AC}$ ) or diets in which $35 \%$ of the concentrate was replaced with FB including wastes of tomato fruit, cucumber, or barley. In each period, 2 goats were randomly assigned to 1 of the dietary treatments. Intakes of FB including tomato, cucumber, and barley were $208 \pm 65,222 \pm 52$, and 209 $\pm 83 \mathrm{~g}$ of dry matter per animal and day, respectively. The replacement of $35 \%$ of concentrate with FB did not compromise nutrient apparent digestibility, total purine derivative urinary excretion, milk yield and composition, and total bacteria and methanogen abundances. Digestible energy and that in methane and urine were higher for $\mathrm{AC}$ than for FB-containing diets, whereas the metabolizable energy value was not affected by diet. The inclusion of tomato and cucumber fruits in FB decreased $\mathrm{N}$ in urine and $\mathrm{CH}_{4}$ emissions compared with $\mathrm{AC}$, which is environmentally relevant. However, tomato-based FB decreased microbial $\mathrm{N}$ flow in the rumen, whereas goats fed cucumber-based FB had the highest values for this measurement. Moreover, FB containing barley or tomato and cucumber led to lower rumen volatile fatty acid and $\mathrm{NH}_{3}-\mathrm{N}$ concentrations, respectively. Milk from goats fed diets including tomato and cucumber-based FB had higher linoleic, linolenic, and total polyunsaturated fatty acid concentrations
\end{abstract}

Received March 27, 2012.

Accepted June 25, 2012.

${ }^{1}$ Corresponding author: molina@eez.csic.es than that from goats fed AC. Overall, our study suggests that tomato and cucumber FB could replace $35 \%$ of the concentrate in the dairy goat diet, reducing animal feeding cost and methane production, leading to higher polyunsaturated fatty acid proportions in milk, and without compromising nutrient utilization or milk yield.

Key words: goat milk, tomato, cucumber, methane

\section{INTRODUCTION}

In Mediterranean countries, ruminant production is limited by poor quality and scarcity of pastures especially during the drought periods. As a consequence, breeders are forced to use expensive cereal-based concentrates. Moreover, the intensification in dairy goat production systems during the last decade makes them strongly dependent on concentrates. Increases in cereal prices (43\% from 2008 to 2011; FAO, 2011) have driven the attention of ruminant nutritionists toward local alternative feedstuffs (Ben Salem, 2010; Molina-Alcaide et al., 2010) to reduce production costs. Byproducts from agriculture may be of interest not only for reducing feeding cost but also to reduce environmental problems associated with byproduct accumulation (Vasta et al., 2008). In the Mediterranean area, greenhouse horticulture represents about $15 \%$ of the world production, Spain being the main producer. This horticulture generates huge amounts of wastes, mainly from tomato and cucumber fruits (about 350,000 and 60,500 t/yr, respectively). Although, these wastes are available during the whole year, amounts can vary among seasons. The use of tomato byproducts for ruminant feeding has been explored (Ben Salem and Znaidi, 2008) but no information is available regarding the inclusion of cucumber in ruminant diets. As tomato and cucumber have high moisture content, their inclusion in feed blocks (FB) would prevent the loss of the nutrients that remain soluble and allow their long-term conservation (Ben Salem and Nefzaoui, 2003).

Nowadays, interest has increased in the development of dietary strategies that could reduce methane emis- 
sions by ruminants (Martín et al., 2010). Methane is an important greenhouse gas that represents a significant energy loss for the animal (2 to $12 \%$ of the gross energy intake). Additionally, research has been focused on feed additives or diet ingredients that could reduce the formation of SFA and increase the concentration of unsaturated FA in ruminant products. As far as we know, few studies have investigated the effect of strategies based on the use of byproducts on milk FA composition (Molina-Alcaide et al., 2010; Modaresi et al., 2011) or methane emissions by ruminants.

Our hypothesis is that tomato and cucumber waste fruits could be ingredients of multinutrient blocks used to partially replace cereal-based concentrates in lactating goat diets without compromising ruminal fermentation and microbiota, and could reduce methane emissions and improve the quality of the milk FA profile. The aim of the present work was to study, in dairy goats, the effect of replacing a cereal-based concentrate with FB on milk yield and composition, nutrient utilization, methane emissions, and bacteria and methanogen abundances.

\section{MATERIALS AND METHODS}

\section{Animals, Wastes, and Diets}

Eight Murciano-Granadina goats $(39.4 \pm 5.39 \mathrm{~kg}$ of $\mathrm{BW}$, mean $\pm \mathrm{SD})$ in the middle of the third lactation were used (50 DIM at the beginning of the experiment). Animals were placed in individual boxes and had free access to water. Animals were cared for and handled in accordance with the Spanish guidelines for experimental animal protection (Royal Decree 1201/2005 of October 10 on the protection of animals used for experimentation or other scientific purposes) in line with the European Convention for the Protection of Vertebrates used for Experimental and other Scientific Purposes (European Directive 86/609).

Tomato and cucumber wastes were collected at the Wastes Treatment Factory in Motril (Granada, Spain), homogenized using a commercial blender (model TR330; Danamix, Fordingbridge, UK) and kept at $-20^{\circ} \mathrm{C}$ before used for FB preparation. Block manufacturing followed the protocol of Molina-Alcaide et al. (2010) with some modifications. For FB manufacturing, solid ingredients were ground $(4 \mathrm{~mm})$ and mixed in a horizontal mixer (model C; P. Prat SA, Sabadell, Spain), with a liquid mixture composed of water, quicklime, salt, beet molasses, urea, and tomato or cucumber waste fruits $(585 \mathrm{~g} /$ $\mathrm{kg}$ of fresh-matter FB) and then high-pressure packed in aluminum molds. Compacted blocks were taken out from the mold and air-dried within 3 to $8 \mathrm{~d}$ and stored until distribution to the animals.
Four experimental diets were formulated with $1 \mathrm{~kg}$ of alfalfa hay $(\mathbf{A})$ plus $1 \mathrm{~kg}$ of concentrate $(\mathbf{C}$; $\operatorname{diet} \mathbf{A C})$, and alfalfa hay, concentrate, and FB (Table 1) containing wastes of tomato (diet ACT) and cucumber (diet ACC) fruits or barley (diet ACB), which replaced $35 \%$ of the concentrate in the control diet. The specific $\mathrm{N}$ and energy requirements of this breed (Aguilera et al., 1990) were considered in the dietary formulation. The amount of alfalfa hay and concentrate supplied to the animals fed AC were sufficient to allow daily milk production of up to $2 \mathrm{~kg}$ per goat. All diets were supplied once daily.

\section{Experimental Procedure}

Four 39-d periods were carried out in a replicated 4 $\times 4$ Latin square design and experimental treatments were randomly assigned within each square, with 8 replications for each diet at the end of the trial. Animals were separated into 4 homogeneous groups based on BW and milk yield, and were fed once per day at 0900 $\mathrm{h}$, with all samples collected before feeding time. After 25-d of adaptation to the corresponding experimental diet, animals were moved to individual metabolism crates. After $3 \mathrm{~d}$ of adaptation to metabolism crates, total feces and urine were collected for $5 \mathrm{~d}$. Individual intakes of diet ingredients were registered throughout the whole trial. No refusals were observed for concentrate. Feed blocks were supplied ad libitum, resulting in average intakes (mean $\pm \mathrm{SD}$ ) of $208 \pm 65,222 \pm 52$, and $209 \pm 83 \mathrm{~g}$ of DM/animal per day for FB based on tomato, cucumber, and barley, respectively. During the sampling period, alfalfa hay and FB refusals from each animal were collected and weighted daily and then pooled and stored at $-20^{\circ} \mathrm{C}$. Urine was collected in buckets with $10 \% \mathrm{HCl}$ (vol/vol) to maintain $\mathrm{pH}$ below 3 and avoid $\mathrm{N}$ losses. Aliquots $(100 \mathrm{~mL})$ of urine were taken for density measurement and analysis of purine derivative (PD) and creatinine concentrations, and also aliquots representing 10 and $20 \%$ of daily feces and urine, respectively, were stored at $-20^{\circ} \mathrm{C}$ for chemical analyses. On d 33, approximately $20 \mathrm{~mL}$ of rumen content was collected from each animal before feeding, using a stomach tube attached to a vacuum pump and strained through 2 layers of cheesecloth. The $\mathrm{pH}$ was measured and aliquots were taken for $\mathrm{NH}_{3}-\mathrm{N}$ and VFA analyses. Freeze-dried aliquots were used for quantification of bacterial and archaeal populations. Every day during the adaptation and sampling periods, goats were hand milked once per day before feeding and milk yield was recorded. Every sampling day (5 d), milk density was measured and aliquots were stored at $-30^{\circ} \mathrm{C}$ without preservatives for the analysis of fat, protein, lactose, casein, TS, and FA contents. 
Table 1. Composition and price of diet ingredients ${ }^{1}$

\begin{tabular}{|c|c|c|c|c|c|}
\hline Item & $\begin{array}{c}\text { Alfalfa } \\
\text { hay }\end{array}$ & Concentrate & FB-T & FB-C & FB-B \\
\hline \multicolumn{6}{|l|}{ Ingredient, $\mathrm{g} / \mathrm{kg}$ of $\mathrm{DM}$} \\
\hline Wheat shorts & - & 350 & - & - & - \\
\hline Corn grain & - & 50 & - & - & - \\
\hline Tomato & - & - & 125 & 0 & 0 \\
\hline Cucumber & - & - & 0 & 67 & 0 \\
\hline Barley & - & 160 & 0 & 0 & 81 \\
\hline Sunflower meal & - & 120 & 94 & 101 & 99 \\
\hline Soybean hulls & - & 90 & - & - & - \\
\hline Corn shorts & - & 100 & - & - & - \\
\hline Soybean meal & - & 90 & - & - & - \\
\hline Wheat straw & - & - & 581 & 620 & 611 \\
\hline Beet molasses & - & - & 29 & 31 & 31 \\
\hline FA salts & - & 4.5 & - & - & - \\
\hline Quicklime & - & 22 & 79 & 85 & 83 \\
\hline $\mathrm{NaCl}$ & - & 3.5 & 47 & 50 & 50 \\
\hline Urea & - & 0 & 34 & 35 & 36 \\
\hline Vitamin-mineral mixture $^{2}$ & - & 25 & 10 & 11 & 11 \\
\hline \multicolumn{6}{|l|}{ Nutrient, $\mathrm{g} / \mathrm{kg}$ of DM } \\
\hline $\mathrm{DM}, \mathrm{g} / \mathrm{kg}$ of fresh matter & 906 & 927 & 907 & 933 & 930 \\
\hline $\mathrm{OM}$ & 881 & 893 & 814 & 818 & 823 \\
\hline $\mathrm{CP}$ & 212 & 170 & 165 & 149 & 152 \\
\hline NDF & 417 & 338 & 466 & 483 & 478 \\
\hline $\mathrm{ADF}$ & 251 & 143 & 273 & 289 & 294 \\
\hline ADL & 59.0 & 25.0 & 44.7 & 40.0 & 41.4 \\
\hline Ether extract & 13.9 & 34.1 & 7.29 & 2.68 & 3.91 \\
\hline Gross energy, $\mathrm{MJ} / \mathrm{kg}$ of $\mathrm{DM}$ & 18.2 & 18.2 & 16.0 & 15.7 & 15.6 \\
\hline \multicolumn{6}{|l|}{ FA, $\%$ of total fat } \\
\hline 14:0 & 5.80 & 1.04 & 1.65 & 5.21 & 3.41 \\
\hline $16: 0$ & 31.6 & 30.4 & 22.8 & 35.3 & 33.3 \\
\hline $16: 1$ & 0.12 & 0.60 & 0.45 & 0.33 & 0.50 \\
\hline $17: 0$ & 0.70 & 0.22 & 0.33 & 0.55 & 0.72 \\
\hline 18:0 & 8.04 & 7.24 & 7.76 & 7.37 & 13.3 \\
\hline cis-9 18:1 & 5.26 & 27.7 & 22.4 & 18.9 & 18.9 \\
\hline cis-9,cis-12 18:2 & 15.1 & 29.4 & 39.9 & 24.9 & 25.1 \\
\hline $20: 0$ & 1.99 & 0.41 & 0.84 & 1.33 & 1.33 \\
\hline $18: 3 n-3$ & 29.5 & 2.68 & 3.04 & 6.05 & 3.49 \\
\hline $22: 0$ & 1.92 & 0.34 & 0.74 & 0.00 & 0.00 \\
\hline Price, $€ / \mathrm{kg}$ of fresh matter & 0.20 & 0.40 & 0.042 & 0.041 & 0.047 \\
\hline
\end{tabular}

${ }^{1}$ FB-T, FB-C, and FB-B are feed blocks (FB) including tomato, cucumber, and barley, respectively.

${ }^{2}$ Formulated (per kilogram) with $\mathrm{NaCl}, 277 \mathrm{~g}$; ash from the 2-stage dried olive cake, $270 \mathrm{~g} ;\left(\mathrm{PO}_{4}\right){ }_{2} \mathrm{H}_{4} \mathrm{Ca}, 250$ g; $\mathrm{MgSO}_{4}, 200 \mathrm{~g}$; CuO, $184 \mathrm{mg}$; I, $25 \mathrm{mg}$; CoO, $8.5 \mathrm{mg}$; Se, $4 \mathrm{mg}$; ZnO, $2.28 \mathrm{mg}$; and 83,500 and 16,700 IU of vitamins $\mathrm{A}$ and $\mathrm{D}$, respectively.

From d 33 to 39, animals were split in 2 blocks of 4 goats; then, each animal within the block was placed in individual open-circuit respiration chambers for 3 $\mathrm{d}$ for methane emissions measurement. A battery of 4 chambers was used, each measuring $1.8-\mathrm{m}$ wide $\times$ $1.8-\mathrm{m}$ deep $\times 1.5-\mathrm{m}$ tall and made of metal frame and polycarbonate. Chamber air temperature was maintained between 10 and $20^{\circ} \mathrm{C}$. Methane measurement interruptions occurred daily at $0900 \mathrm{~h}$ for diet supply, milking, and chamber floor cleaning. These interruptions had little effect on the daily methane emissions, as they lasted for around $10 \mathrm{~min}$ for each chamber and occurred when the corresponding exhaust duct was not being sampled. Fluxes were calculated twice per day and then averaged to derive the 24 -h emission value.

\section{Real-Time PCR Analysis}

The abundances of total bacteria and archaea populations in samples from the rumen of goats were quantified using real-time quantitative PCR (qPCR). Extraction and purification of DNA were performed from approximately 50-mg freeze-dried samples, using the repeated bead beating (Mini-Beadbeater; BioSpec Products Inc., Bartlesville, OK) plus column procedure of $\mathrm{Yu}$ and Morrison (2004). Extracted DNA yield and purity were assessed by using a NanoDrop ND-1000 spectrophotometer (NanoDrop Technologies Inc., Wilmington, DE). The DNA samples were used as templates to quantify the copy numbers of $16 \mathrm{~S}$ rRNA (for bacteria) and of methyl coenzyme $\mathrm{M}$ reductase $\mathrm{A}$ 
gene (for methanogenic archaea). For each microbial group, 3 different aliquots of DNA were analyzed using qPCR as described by Wright et al. (2009) using the following primer pairs: forward: 5'-CGGCAACGAGCGCAACCC-3' and reverse: 5'-CCATTGTAGCACGTGTGTAGCC-3' for total bacteria (Denman and McSweeney, 2006), and forward: 5'-GGATTAGATACCCSGGTAGT-3' and reverse: 5'-GTTGARTCCAATTAAACCGCA-3' for methanogenic archaea (Christophersen, 2007). The external standards used for the qPCR amplifications have been validated previously for rumen bacteria (Denman and McSweeney, 2006) and methanogenic archaea (Christophersen, 2007).

\section{Chemical Analyses}

Dry matter (method 934.01), ash (method 942.05), ether extract (method 920.39), and N (method 984.13) in samples of supplied and refused diet ingredients, feces, and urine were determined according to AOAC International (2005). The $\mathrm{N}$ values of feeds, refusals, feces, and urine, determined by the Kjeldahl procedure, were converted to CP by multiplying by 6.25 . The analyses of NDF and ADF were carried out according to Van Soest et al. (1991) using an Ankom220 fiber analyzer unit (Ankom Technology Corp., Macedon, NY) with $\alpha$-amylase for NDF analysis in concentrate samples, and both NDF and ADF were expressed exclusive of residual ash. Lignin was determined by solubilization of cellulose with $72 \%$ sulfuric acid. Free, protein-bound, and fiber-bound condensed tannins were sequentially extracted following the procedure described by PerezMaldonado and Norton (1996). Condensed tannins from quebracho powder (Roy Wilson Dickson Ltd., Mold, UK) were used as a standard. The fat content in feedstuffs and feces was measured by extraction with petroleum ether (boiling point, 40 to $60^{\circ} \mathrm{C}$ ). The energy content of samples was determined by using an adiabatic calorimeter (model 1356; Parr Instruments Co., Moline, IL). Rumen content samples were also analyzed for total and individual VFA by gas chromatography following the method described by Isac et al. (1994). The $\mathrm{NH}_{3}-\mathrm{N}$ concentration was determined by a colorimetric method (Weatherburn, 1967).

Milk TS content was determined by lyophilization of milk samples. The total $\mathrm{N}$ content was determined by the Kjeldahl procedure. Nonprotein N was analyzed in samples of milk filtrates after precipitation with $12 \%$ (wt/vol) trichloroacetic acid solution. Noncasein N content was determined in milk filtrates after precipitation with $10 \%$ (wt/vol) acetic acid at a $\mathrm{pH}$ of 4.1 (Recio et al., 1997). Values of $\mathrm{N}$ in milk were converted to the corresponding protein by multiplying by 6.38 . The milk fat content was measured following the Gerber method (Pearson, 1976). For methane measurements, air stream in each duct was subsampled, and methane concentration was measured continuously using a gas analyzer ADC MGA3000 (Spurling Works, Hertfordshire, UK).

The purine bases (PB) concentration in feeds and creatinine and $\mathrm{PD}$ in urine were determined according to Balcells et al. (1992) using an HPLC system, which consisted of a multisolvent delivery system (model 510; Waters Corp., Milford, MA), an injector (Waters 717 plus autosampler; Waters Corp.), a multiwavelength detector (model 481; Lambda-Max LC spectrophotometer; Waters Corp.; set to $205 \mathrm{~nm}$ ), and a double $4.0 \times 250-\mathrm{mm}$ C18 ODS-2 analytical column (Waters Spherisorb). The PB and PD were quantified by peak integration using the Waters HPLC systems software Millenium32.

Extraction of total FA in samples of feedstuffs was performed following the recommendations of Devillard et al. (2006). The FA methyl esters (FAME) were prepared according to a standard procedure described previously (Wąsowska et al., 2006). For milk FA composition analysis, FA were extracted and transesterified to FAME as described by Abecia et al. (2012). Milk FAME were separated and quantified using a gas chromatograph (model Focus GC; Thermo Scientific, Milan, Italy) equipped with a flame-ionization detector and a 100-m fused silica capillary column (0.25-mm i.d., 0.2$\mu \mathrm{m}$ film thickness; TR-CN100; Teknokroma, Barcelona, Spain) and helium as the carrier gas. The total FAME profile in a $1-\mu \mathrm{L}$ sample volume at a split ratio of 1:50 was determined using a temperature gradient program (Shingfield et al., 2003). Peaks were routinely identified based on retention time comparisons with authentic FAME standards when available (47885-U, N5252, and O5632: Sigma-Aldrich, Madrid, Spain; 20-1813-9: Larodan Fine Chemicals, Malmö, Sweden) and chromatograms reported in the literature (e.g., Shingfield et al., 2003). Identification was validated based on GCMS analysis of FAME. The mass spectrometer (ITQ 900; Thermo Scientific, Austin, TX) was operated at $225^{\circ} \mathrm{C}$ in the electron impact ionization mode and mass spectra were recorded with $70-\mathrm{eV}$ ionization energy using helium as the carrier gas and the same temperature gradient used for routine analysis of FAME (Shingfield et al., 2003). Although the mass spectra of FAME provides limited information concerning FA structure, comparisons with an online reference library of electron impact ionization spectra (http://lipidlibrary.aocs.org/ $\mathrm{ms} / \mathrm{masspec} . \mathrm{html}$ ) and chromatographic retention data allowed the identification of $>96 \%$ of FAME in all samples. 


\section{Calculations and Statistical Analyses}

Nutrient apparent digestibilities were determined from corresponding intakes and losses in feces. Nitrogen and energy balances were obtained, taking into account $\mathrm{N}$ and energy losses in urine, feces, and milk, and energy lost in methane $(0.890 \mathrm{MJ} / \mathrm{mol}$ of methane). The amount of $\mathrm{N}$ and energy excreted into milk was also considered.

Milk protein $\mathrm{N}$ content was calculated as the difference between total and NPN in milk. The casein N in milk was calculated as the difference between total and noncasein $\mathrm{N}$. The whey $\mathrm{N}$ in milk was calculated as the difference between milk protein and casein N. Milk lactose was calculated as the difference between the amount of TS and protein, fat, and total ash in milk.

Absorbed PB were calculated as daily PD urinary excretion $/ 0.74$. The 0.74 value was obtained from Mota et al. (2008) for the PB recovery rates in goats. Microbial N flow was estimated from absorbed PB and PB:N ratios in the total bacterial pellet obtained in previous experiments using rumen-fistulated goats fed similar diets (M. Romero-Huelva, unpublished data).

The flux of methane for each chamber was calculated for the last $2 \mathrm{~d}$ of the measurement period from the chamber fresh-air intake and exhaust concentrations and mean air flows (L / min). The SPSS for Windows software (version 19.0, 2010; SPSS Inc., Chicago, IL) was used for data entry and statistical analysis. Data were analyzed by the GLM using the repeated-measures ANOVA following a $4 \times 4$ Latin square design. Diet was considered as fixed effect, and period and animal were considered as random effects. When a significant effect of diet was found, post hoc comparison of means was made using the least significant difference test: $\alpha_{c}$ $=1-(1-\alpha)^{k}$, where $\alpha_{c}$ is the comparison wise error rate, $\alpha$ is the significance level, and $k$ is the number of comparisons performed. Differences were considered significant at $P<0.05$, and $P<0.10$ values were declared as trends and discussed.

\section{RESULTS AND DISCUSSION}

\section{Feed Composition}

Analyses of waste fruits carried out in different seasons showed that chemical composition was very stable throughout the year (data not shown). The absence of differences may rely upon the homogeneous conditions when vegetables are produced under the controlled conditions of greenhouses. The FB had lower OM, CP, gross energy, and ether extract contents, but higher NDF, ADF, and ADL contents compared with the concentrate (Table 1). Crude protein and energy contents were similar for all FB. Tomato- and cucumber-based FB were rich in free, fiber-bound, and total condensed tannins $(1.7,15.5$, and $20 \mathrm{~g} / \mathrm{kg}$ of DM, respectively) compared with concentrate and barley-based FB (1.2, 12.3 , and $15 \mathrm{~g} / \mathrm{kg}$ of $\mathrm{DM}$, respectively). However, protein-bound condensed tannin concentrations in cucumber-based blocks and concentrate were similar $(1.85 \mathrm{~g} / \mathrm{kg}$ of DM). Feed blocks including tomato and cucumber had higher percentages of linoleic (LEA; cis-9,cis-12 18:2) and linolenic acid (LNA; cis-9,cis12,cis-15 18:3), respectively, compared with the concentrate. Considering the amount of cereals included in the concentrate and the FB used in the present work, the average intakes and the current cost of diet ingredients in Spain (Table 1), a reduction of $22 \%$ in feeding cost may be achieved by using diets including FB, which is in agreement with observations from other authors (Molina-Alcaide et al., 2010). Although this is a substantial reduction in feeding cost, waste transportation and FB manufacturing should be considered in each situation to estimate the profit margins.

\section{Intake, Nutrient Apparent Digestibility, and Energy and $N$ Utilization}

Intake of DM (Table 2) tended to be lower $(P=$ $0.085)$ with diets containing FB compared with the control diet, which may be associated with the lower $(P$ $=0.043)$ concentrate $+\mathrm{FB}$ intake observed in goats fed FB. Fat intake was about $23 \%$ higher $(P=0.02)$ for AC than for ACT, ACC, and ACB. Average daily intakes of FB were in the line of those found by Molina-Alcaide et al. (2010) for Murciano-Granadina dairy goats fed diets including FB containing olive cake and lower than those found by Ben Salem and Znaidi (2008) for lambs fed tomato- and olive cake-based FB. Sansoucy (1986) also reported a wide variation of block intake per animal per day in sheep and goats.

Although the apparent digestibility of nutrients was unaffected $(P \geq 0.32)$ by diet, the replacement of concentrate with FB tended $(P=0.06)$ to reduce the average digestibility of fat. Although similar results were reported by Molina-Alcaide et al. (2010) for DM and OM digestibility in lactating Murciano-Granadina goats fed diets including olive cake-based FB, Ben Salem and Znaidi (2008) reported decreased DM and OM digestibility when the concentrate was partially replaced with olive cake- or tomato-based FB in Barbarine lambs fed diets based on cereal straw. These differences may rely upon factors such as animal species, physiological state, and FB and diet formulation. Moreover, in the present work, the partial replacement of the concentrate with FB did not reduce NDF or ADF apparent digestibility. 
Table 2. Intake $(\mathrm{g} / \mathrm{d})$ and apparent digestibility $(\mathrm{g} / \mathrm{g})$ of nutrients in dairy goats fed the experimental diets $(\mathrm{n}=8)$

\begin{tabular}{lcccccc}
\hline \multicolumn{7}{c}{ Diet $^{1}$} \\
\cline { 2 - 5 } Item & AC & ACT & ACC & ACB & SEM & $P$-value \\
\hline Intake & & & & & \\
DM & 1,631 & 1,548 & 1,555 & 1,554 & 37.9 & 0.08 \\
Alfalfa hay & 705 & 737 & 730 & 743 & 39.6 & 0.84 \\
Concentrate & $925^{\mathrm{b}}$ & $602^{\mathrm{a}}$ & $602^{\mathrm{a}}$ & $602^{\mathrm{a}}$ & 4.05 & $<0.001$ \\
Blocks & $0^{\mathrm{a}}$ & $208^{\mathrm{b}}$ & $222^{\mathrm{b}}$ & $209^{\mathrm{b}}$ & 23.4 & $<0.001$ \\
Concentrate + FB & $925^{\mathrm{b}}$ & $811^{\mathrm{a}}$ & $824^{\mathrm{a}}$ & $811^{\mathrm{a}}$ & 23.5 & 0.043 \\
OM & 1,439 & 1,360 & 1,368 & 1,363 & 38.5 & 0.51 \\
Fat & $41.6^{\mathrm{b}}$ & $33.0^{\mathrm{a}}$ & $32.0^{\mathrm{a}}$ & $31.4^{\mathrm{a}}$ & 0.87 & 0.02 \\
CP & 311 & 300 & 297 & 300 & 6.96 & 0.70 \\
NDF & 595 & 587 & 601 & 599 & 22.2 & 0.98 \\
ADF & 302 & 313 & 320 & 317 & 14.7 & 0.91 \\
Apparent digestibility & & & & & & \\
DM & 0.69 & 0.68 & 0.67 & 0.69 & 0.009 & 0.53 \\
OM & 0.72 & 0.71 & 0.69 & 0.71 & 0.009 & 0.56 \\
Fat & 0.80 & 0.73 & 0.74 & 0.75 & 0.017 & 0.06 \\
CP & 0.78 & 0.76 & 0.76 & 0.77 & 0.009 & 0.32 \\
NDF & 0.54 & 0.55 & 0.54 & 0.57 & 0.011 & 0.90 \\
ADF & 0.46 & 0.46 & 0.47 & 0.49 & 0.016 & 0.89 \\
\hline
\end{tabular}

${ }^{a, b}$ Within a row, means not bearing a common superscript letter differ $(P<0.05)$.

${ }^{1} \mathrm{AC}=1,000 \mathrm{~g}$ of alfalfa hay and 1,000 $\mathrm{g}$ of concentrate; $\mathrm{ACT}=1,000 \mathrm{~g}$ of alfalfa hay, $650 \mathrm{~g}$ of concentrate, and $231.5 \pm 68.8 \mathrm{~g}$ (mean $\pm \mathrm{SD}$ ) of tomato feed block (FB); $\mathrm{ACC}=1,000 \mathrm{~g}$ of alfalfa hay, $650 \mathrm{~g}$ of concentrate, and $239 \pm 58.9 \mathrm{~g}$ (mean $\pm \mathrm{SD}$ ) of cucumber $\mathrm{FB} ; \mathrm{ACB}=1,000 \mathrm{~g}$ of alfalfa hay, $650 \mathrm{~g}$ of concentrate, and 223 $\pm 87.6 \mathrm{~g}$ (mean $\pm \mathrm{SD}$ ) of barley FB (fresh-matter basis).

As increased levels of concentrate in ruminant diets are often associated with higher DM and OM and lower NDF digestibilities, the use of tomato- and cucumberbased FB seems to be a successful strategy to partially replace the concentrate in the goat diet.

The $\mathrm{N}$ intake per kilogram of metabolic BW (Table $3)$ was similar $(P=0.38)$ for $\mathrm{AC}$ and those diets including FB. Whereas fecal $\mathrm{N}$ was similar $(P=0.92)$ among diets, urine $\mathrm{N}$ was higher $(P=0.04)$ for animals receiving the $\mathrm{AC}$ diet than for those fed diets including FB. The percentage of milk protein $\mathrm{N}$ in relation to the $\mathrm{N}$ balance was lower $(P=0.04)$ for animals fed diets including tomato-based FB than for those fed the other diets, in agreement with Bequette et al. (1999), who stated that the AA profile of different protein sources may have an influence on body retention and milk yield of $\mathrm{N}$. Overall, the inclusion of tomato and cucumber wastes in FB did not compromise $\mathrm{N}$ intake or utilization, promoting lower $\mathrm{N}$ excretion in urine compared with animals fed the control diet, which has important environmental implications (Vasta et al., 2008).

The energy intake was higher $(P=0.03)$ for AC than for ACT, ACC, and ACB. Fecal energy was similar ( $P$ $=0.52$ ) among diets, whereas urine energy was higher $(P=0.01)$ for AC than for those including FB. Digestible energy and energy in methane were higher $(P<$ 0.05) for AC than for FB-containing diets. Our results are in agreement with previous observations made by
Cerrillo et al. (1999) who noted a reduction in digestible energy when feeding goats with decreasing amounts of concentrate. The percentage of $\mathrm{ME}$ in relation to the digestible energy was affected $(P=0.047)$ by diet, the lowest value being for the control diet. Therefore, the lower values for energy digestibility found in goats supplemented with FB were compensated with lower methane and urine energy losses (Table 3) and, thus, resulted in similar values of $\mathrm{ME}(P=0.57)$.

\section{Microbial N Flow}

Creatinine excretion varied from 183 to $200 \mu \mathrm{mol} / \mathrm{kg}$ of $\mathrm{BW}^{0.75}$. The urinary excretion (Table 4 ) of total PD were similar $(P=0.72)$ among treatments, with values being lower than those obtained by Mota et al. (2008) in Murciano-Granadina goats fed alfalfa plus concentrate $\left(745 \mu \mathrm{mol}\right.$ of $\mathrm{PD} / \mathrm{kg}$ of $\left.\mathrm{BW}^{0.75}\right)$. The lowest $(P<0.05)$ microbial $\mathrm{N}$ flow was found in goats fed ACT, followed by goats fed $\mathrm{AC}$ and $\mathrm{ACB}$, and the highest value corresponded to goats fed ACC. Low availability of protein and nutritive value have been reported for tomato by Ventura et al. (2009). Although microbial N flow relies upon the synchronized supply of nitrogen and energy to microorganisms (Bach et al., 2005), which was improved with diets including $\mathrm{FB}$, other factors such as energy and nitrogen quality in the 3 types of FB could influence digestibility, $\mathrm{N}$, and energy utilization. 
Table 3. Mean values for BW, nitrogen, and energy utilization in dairy goats fed the experimental diets $(\mathrm{n}=8)$

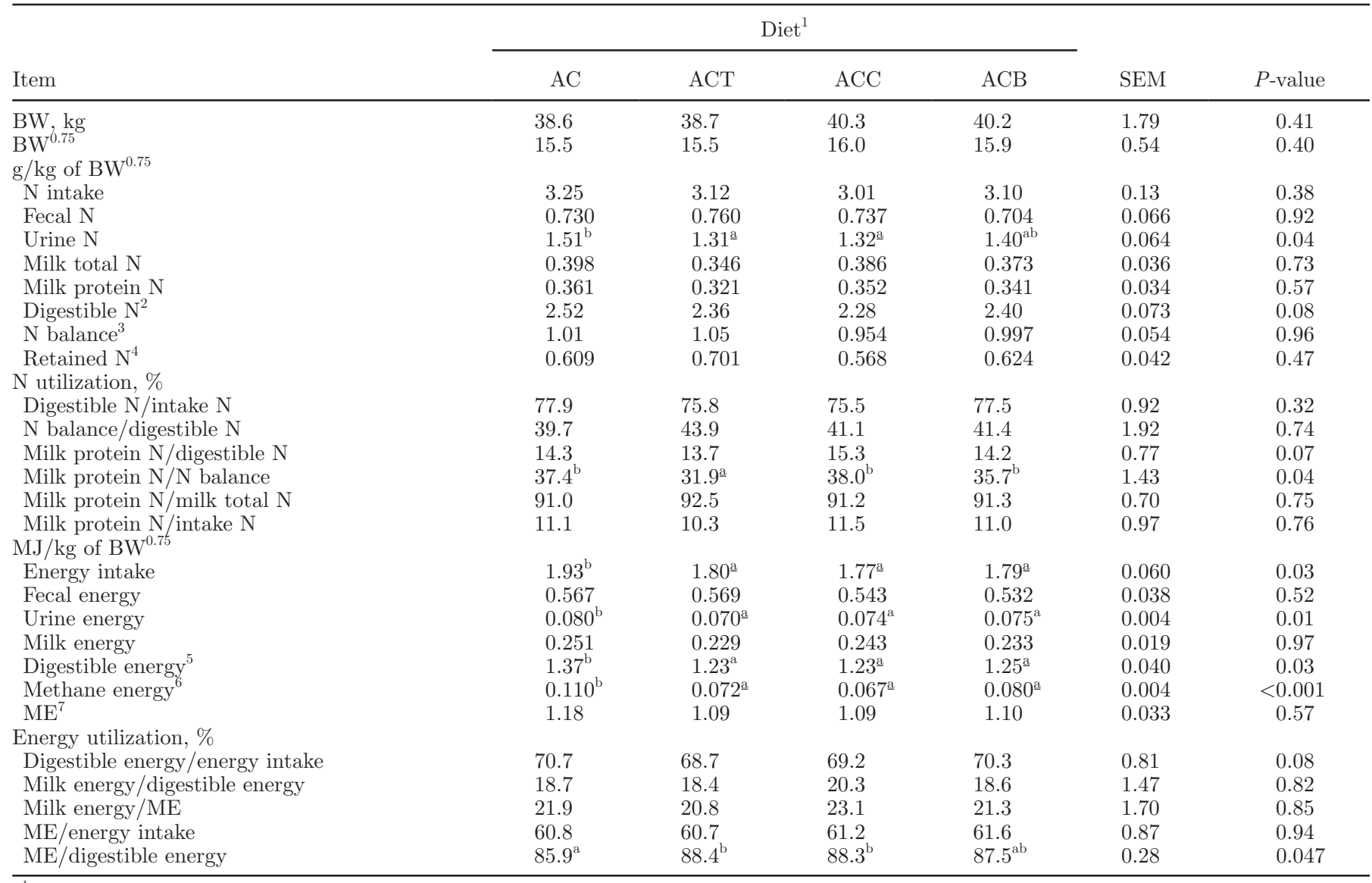

${ }_{\mathrm{a}, \mathrm{b}}$ Within a row, means not bearing a common superscript letter differ $(P<0.05)$.

${ }^{1} \mathrm{AC}=1,000 \mathrm{~g}$ of alfalfa hay and 1,000 $\mathrm{g}$ of concentrate; $\mathrm{ACT}=1,000 \mathrm{~g}$ of alfalfa hay, $650 \mathrm{~g}$ of concentrate, and $231.5 \pm 68.8 \mathrm{~g}(\mathrm{mean} \pm \mathrm{SD}$ ) of tomato feed block; $\mathrm{ACC}=1,000 \mathrm{~g}$ of alfalfa hay, $650 \mathrm{~g}$ of concentrate, and $239 \pm 58.9 \mathrm{~g}$ (mean $\pm \mathrm{SD}$ ) of cucumber feed block; ACB = 1,000 $\mathrm{g}$ of alfalfa hay, $650 \mathrm{~g}$ of concentrate, and $223 \pm 87.6 \mathrm{~g}$ (mean $\pm \mathrm{SD}$ ) of barley feed block (fresh-matter basis).

${ }^{2}$ Digestible $\mathrm{N}=$ intake $\mathrm{N}-$ fecal $\mathrm{N}$.

${ }^{3}$ Nitrogen balance $=$ digestible $\mathrm{N}-$ urine $\mathrm{N}$.

${ }^{4}$ Retained $\mathrm{N}=\mathrm{N}$ balance - milk total $\mathrm{N}$.

${ }^{5}$ Digestible energy $=$ energy intake - fecal energy.

${ }^{6}$ Methane energy $=0.890 \mathrm{MJ} / \mathrm{mol}$ of $\mathrm{CH}_{4}$ (Newbold et al., 2007).

${ }^{7} \mathrm{ME}=$ digestible energy - urine energy - methane energy.

\section{Milk Yield and Composition}

Neither milk yield nor its component concentrations (Table 4) were affected by the partial replacement of concentrate with FB in diets of dairy goats. Only differences on the yield and composition of lactose were found $(P<0.05)$, with higher values with $\mathrm{ACB}$, followed by $\mathrm{AC}$ and $\mathrm{ACC}$, and finally $\mathrm{ACT}$. In contrast to our results, Molina-Alcaide et al. (2010) found lower values for milk production in goats fed $\mathrm{FB}$ containing olive cake, but without any differences in milk composition. On the other hand, the efficiency of feed utilization was similar among diets, showing the potential of FB to successfully replace cereal-based concentrates in ruminant diets.
Some research has been conducted on changes in milk FA composition in small ruminants when feeding agro-industrial byproducts, such as olive cake (MolinaAlcaide et al., 2010), olive leaves (Tsiplakou and Zervas, 2008), pomegranate seed pulp (Modaresi et al., 2011), and tomato pomace (Romano et al., 2010). The most abundant individual FA in milk found in the present work were palmitic, oleic, capric, myristic, stearic, and lauric acids, in line of those previously reported by Sanz Sampelayo et al. (2000) in Murciano-Granadina dairy goats. Milk from goats fed diets including FB had (Table 5) higher $(P<0.05)$ myristoleic (cis-9 14:1), palmitoleic (cis-9 16:1), 17:0, anteiso 17:0, LEA, LNA, and total PUFA concentrations than those fed AC; a decrease $(P=0.04)$ of about $12 \%$ for the concentration 
Table 4. Effect of diet on milk production and composition, feed efficiency, urinary excretion of purine derivatives, and microbial $\mathrm{N}$ flow in dairy goats fed the experimental diets $(n=8)$

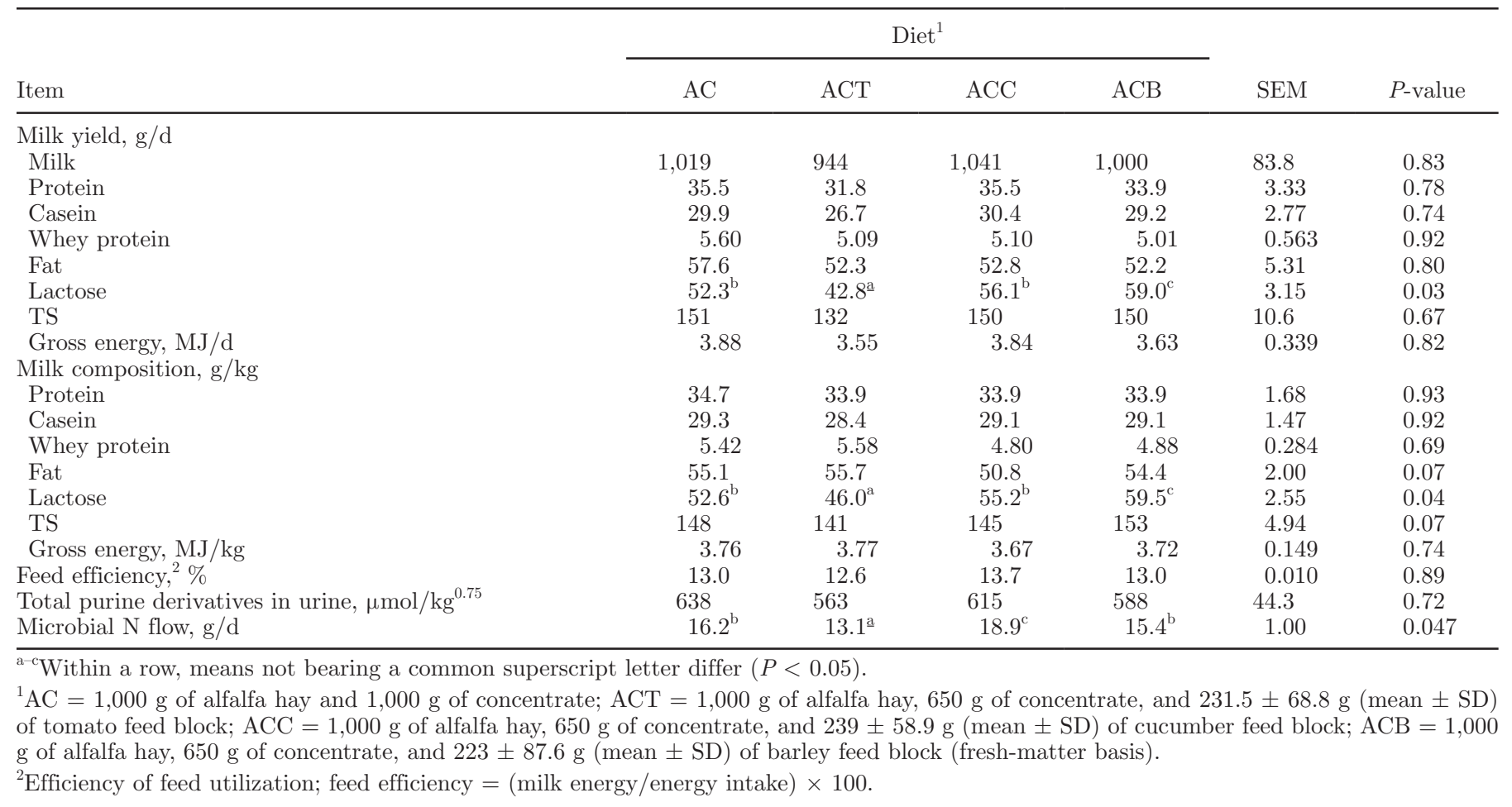

of stearic acid was observed in ACT and ACB. Additionally, the concentrate replacement with FB tended to decrease $(P=0.10)$ the $\Sigma \mathrm{n}-6 / \Sigma \mathrm{n}-3$ ratio in goat milk, which appears to be of great importance for human health (Simopoulos, 2002).

Milk fat of goats fed ACT increased $(P=0.04)$ cis9,trans-11 CLA content, and ACB tended $(P=0.06)$ to decrease trans-11 18:1 content. The higher $(P<0.05)$ accumulation of cis-9,trans-12 18:2 and trans-11,cis-15 18:2, both intermediates of the LNA biohydrogenation, in milk from goats fed ACT suggests an incomplete biohydrogenation of LNA. Additionally, it could be speculated that tomato seeds were partially crushed during the manufacture of blocks, making a fraction of its FA accessible to biohydrogenating bacteria, leading to accumulation of biohydrogenation intermediates, whereas another FA fraction could remain protected, making larger amounts of PUFA available in the small intestine for absorption. Similar results were obtained by Abbeddou et al. (2011) and Romano et al. (2010), who reported increased accumulations of CLA (43.3 and $19.8 \%$, respectively) and total PUFA (5.17 and 6.43\%, respectively) in the milk of sheep supplemented with tomato byproducts compared with the control diet.

In addition to FA supply, other factors such as energy supply, proportion of fiber or concentrate, and the presence of plant secondary compounds should be con- sidered when the effects of dietary treatments on milk FA profile are assessed (Leiber et al., 2005). Therefore, the higher accumulation of LNA in the milk of goats receiving FB could be associated with changes in the ruminal ecosystem due to energy shortage or specific secondary plant metabolite presence in the diet (Leiber et al., 2005). Moreover, the improved synchronization of nutrient supply allowed when using FB in ruminant feeding (Ben Salem and Nefzaoui, 2003) might be responsible of better FA absorption in the small intestine.

Dietary intakes $(\mathrm{mg} / \mathrm{d})$ of LNA, LEA, oleic (cis-9 18:1), and stearic (data not shown) acids showed that goats fed the diet including FB consumed less unsaturated FA and SFA (27 and 24\%, respectively) than those under the control diet $(P \leq 0.034)$. However, the recovery rates (g of FA excreted in milk/g of FA intake; data not shown) for LNA, LEA, and oleic acid were higher $(27,28$, and $25 \%$, respectively; $P \leq 0.02)$ in animals fed FB diets compared with the control diet, in agreement with Abbeddou et al. (2011).

Because LEA, LNA, and CLA, are considered healthy for consumers due to their beneficial effects in the prevention of cardiovascular diseases and hypertension in humans (Kromhout et al., 2010), the inclusion of tomato and cucumber wastes in the form of FB in goats feeding could be an option to improve the nutritional quality of goat dairy products. 
Table 5. Fatty acid composition (g/100 g of identified FA) of milk fat of dairy goats fed the experimental diets $(\mathrm{n}=8)$

\begin{tabular}{|c|c|c|c|c|c|c|}
\hline \multirow[b]{2}{*}{ Item } & \multicolumn{4}{|c|}{$\operatorname{Diet}^{1}$} & \multirow[b]{2}{*}{ SEM } & \multirow[b]{2}{*}{$P$-value } \\
\hline & $\mathrm{AC}$ & $\mathrm{ACT}$ & $\mathrm{ACC}$ & $\mathrm{ACB}$ & & \\
\hline \multicolumn{7}{|l|}{ SFA } \\
\hline $4: 0$ & 1.54 & 1.39 & 1.48 & 1.44 & 0.041 & 0.74 \\
\hline $6: 0$ & 2.41 & 2.32 & 2.29 & 2.30 & 0.081 & 0.64 \\
\hline $8: 0$ & 3.06 & 2.98 & 2.48 & 2.98 & 0.086 & 0.31 \\
\hline $10: 0$ & 11.7 & 11.7 & 11.5 & 11.8 & 0.283 & 0.84 \\
\hline $11: 0$ & 0.11 & 0.12 & 0.11 & 0.11 & 0.015 & 0.86 \\
\hline $12: 0$ & 6.01 & 6.45 & 6.33 & 6.39 & 0.350 & 0.44 \\
\hline $14: 0$ & 10.9 & 11.1 & 11.3 & 11.3 & 0.179 & 0.63 \\
\hline $15: 0$ & 0.80 & 0.86 & 0.90 & 0.90 & 0.044 & 0.07 \\
\hline iso $15: 0$ & 0.19 & 0.21 & 0.23 & 0.21 & 0.017 & 0.07 \\
\hline anteiso $15: 0$ & 0.27 & 0.29 & 0.30 & 0.30 & 0.018 & 0.15 \\
\hline $16: 0$ & 29.6 & 28.6 & 29.0 & 29.3 & 0.585 & 0.73 \\
\hline $17: 0$ & $0.51^{\mathrm{a}}$ & $0.57^{\mathrm{b}}$ & $0.59^{\mathrm{b}}$ & $0.57^{\mathrm{b}}$ & 0.017 & $<0.001$ \\
\hline anteiso $17: 0$ & $0.34^{\mathrm{a}}$ & $0.38^{\mathrm{b}}$ & $0.37^{\mathrm{b}}$ & $0.38^{\mathrm{b}}$ & 0.016 & 0.04 \\
\hline $18: 0$ & $6.93^{\mathrm{b}}$ & $6.15^{\mathrm{a}}$ & $6.24^{\mathrm{ab}}$ & $6.00^{\mathrm{a}}$ & 0.378 & 0.04 \\
\hline $20: 0$ & 0.19 & 0.18 & 0.19 & 0.18 & 0.010 & 0.51 \\
\hline $21: 0$ & 0.058 & 0.069 & 0.069 & 0.077 & 0.003 & 0.26 \\
\hline $22: 0$ & 0.053 & 0.049 & 0.064 & 0.067 & 0.004 & 0.07 \\
\hline Total SFA & 74.7 & 73.4 & 73.4 & 74.4 & 0.458 & 0.58 \\
\hline \multicolumn{7}{|l|}{ MUFA } \\
\hline cis-9 14:1 & $0.20^{\mathrm{a}}$ & $0.24^{\mathrm{b}}$ & $0.24^{\mathrm{b}}$ & $0.23^{\mathrm{b}}$ & 0.014 & 0.04 \\
\hline cis-9 $16: 1$ & $0.74^{\mathrm{a}}$ & $0.80^{\mathrm{b}}$ & $0.82^{\mathrm{b}}$ & $0.82^{\mathrm{b}}$ & 0.019 & 0.02 \\
\hline trans-9 $16: 1^{2}$ & 0.62 & 0.64 & 0.65 & 0.62 & 0.021 & 0.57 \\
\hline cis-9 $18: 1^{3}$ & 15.9 & 16.1 & 16.4 & 15.7 & 0.550 & 0.84 \\
\hline cis-11 18:1 & 0.30 & 0.35 & 0.33 & 0.34 & 0.010 & 0.63 \\
\hline cis-12 18:1 & 0.20 & 0.25 & 0.22 & 0.23 & 0.010 & 0.07 \\
\hline cis-13 18:1 & 0.042 & 0.047 & 0.043 & 0.045 & 0.003 & 0.57 \\
\hline cis-16 18:1 & 0.045 & 0.044 & 0.038 & 0.044 & 0.003 & 0.69 \\
\hline trans-5 18:1 & 0.020 & 0.021 & 0.016 & 0.018 & 0.001 & 0.56 \\
\hline trans-6-8 $18: 1$ & $0.20^{\mathrm{a}}$ & $0.24^{\mathrm{b}}$ & $0.20^{\mathrm{a}}$ & $0.21^{\mathrm{a}}$ & 0.012 & 0.048 \\
\hline trans-9 18:1 & $0.22^{\mathrm{a}}$ & $0.26^{\mathrm{b}}$ & $0.22^{\mathrm{a}}$ & $0.22^{\mathrm{a}}$ & 0.014 & 0.03 \\
\hline trans-10 18:1 & 0.33 & 0.43 & 0.34 & 0.36 & 0.047 & 0.23 \\
\hline trans-11 18:1 & 0.82 & 0.89 & 0.78 & 0.68 & 0.060 & 0.06 \\
\hline cis-11 20:1 & 0.071 & 0.075 & 0.076 & 0.071 & 0.004 & 0.70 \\
\hline Total MUFA & 19.7 & 20.3 & 20.4 & 19.6 & 0.498 & 0.76 \\
\hline \multicolumn{7}{|l|}{ PUFA } \\
\hline cis-9,cis-12 18:2 & $1.94^{\mathrm{a}}$ & $2.17^{\mathrm{b}}$ & $2.21^{\mathrm{b}}$ & $2.11^{\mathrm{ab}}$ & 0.094 & 0.048 \\
\hline cis-9,trans-12 18:2 & $0.054^{\mathrm{b}}$ & $0.049^{\mathrm{b}}$ & $0.046^{\mathrm{ab}}$ & $0.042^{\mathrm{a}}$ & 0.002 & 0.01 \\
\hline cis-9,trans-11 CLA & $0.57^{\mathrm{ab}}$ & $0.62^{\mathrm{b}}$ & $0.55^{\mathrm{ab}}$ & $0.50^{\mathrm{a}}$ & 0.048 & 0.04 \\
\hline trans-8,cis-13 18:2 & 0.090 & 0.093 & 0.084 & 0.090 & 0.004 & 0.07 \\
\hline trans -9, cis-12 18:2 & 0.030 & 0.036 & 0.033 & 0.035 & 0.002 & 0.38 \\
\hline trans-11,cis-15 18:2 & $0.037^{\mathrm{a}}$ & $0.053^{\mathrm{b}}$ & $0.048^{\mathrm{ab}}$ & $0.047^{\mathrm{ab}}$ & 0.005 & 0.02 \\
\hline cis-6,cis-9,cis-12 18:3 & 0.017 & 0.025 & 0.023 & 0.028 & 0.002 & 0.39 \\
\hline cis-9,cis-12,cis-15 18:3 & $0.39^{\mathrm{a}}$ & $0.54^{\mathrm{b}}$ & $0.52^{\mathrm{b}}$ & $0.54^{\mathrm{b}}$ & 0.036 & 0.04 \\
\hline $20: 3 n-6$ & 0.020 & 0.027 & 0.023 & 0.038 & 0.004 & 0.099 \\
\hline $20: 4 n-6$ & 0.20 & 0.23 & 0.26 & 0.22 & 0.011 & 0.076 \\
\hline Total PUFA & $3.34^{\mathrm{a}}$ & $3.83^{\mathrm{b}}$ & $3.80^{\mathrm{b}}$ & $3.65^{\mathrm{b}}$ & 0.108 & 0.03 \\
\hline \multicolumn{7}{|l|}{ According to origin 4} \\
\hline$<16$-carbon FA & 37.2 & 37.6 & 37.1 & 38.0 & 0.596 & 0.79 \\
\hline 16-carbon FA & 30.9 & 30.0 & 30.5 & 30.8 & 0.593 & 0.77 \\
\hline$>16$-carbon FA & 29.6 & 29.9 & 30.0 & 28.8 & 0.870 & 0.79 \\
\hline$\Sigma n-6 / \Sigma n-3$ & 5.55 & 4.54 & 4.76 & 4.34 & 0.009 & 0.098 \\
\hline
\end{tabular}

${ }^{a, b}$ Within a row, means not bearing a common superscript letter differ $(P<0.05)$.

${ }^{1} \mathrm{AC}=1,000 \mathrm{~g}$ of alfalfa hay and $1,000 \mathrm{~g}$ of concentrate; $\mathrm{ACT}=1,000 \mathrm{~g}$ of alfalfa hay, $650 \mathrm{~g}$ of concentrate, and $231.5 \pm 68.8 \mathrm{~g}$ (mean $\pm \mathrm{SD}$ ) of tomato feed block; $\mathrm{ACC}=1,000 \mathrm{~g}$ of alfalfa hay, $650 \mathrm{~g}$ of concentrate, and $239 \pm 58.9 \mathrm{~g}$ (mean $\pm \mathrm{SD}$ ) of cucumber feed block; $\mathrm{ACB}=1,000 \mathrm{~g}$ of alfalfa hay, $650 \mathrm{~g}$ of concentrate, and 223 $\pm 87.6 \mathrm{~g}$ (mean $\pm \mathrm{SD}$ ) of barley feed block (fresh-matter basis).

${ }^{2}$ Contains iso C17:0.

${ }^{3}$ Contains trans-12, cis-10 + trans-15 C18:1 as minor components.

${ }^{4}<16$-carbon FA represent de novo synthesized FA; >16-carbon FA represent preformed FA taken up from circulation; 16-carbon FA are derived from both sources. 
Table 6. Methane emissions, average values for $\mathrm{pH}, \mathrm{NH}_{3}-\mathrm{N}$, total and individual VFA, and microbial densities in the rumen of dairy goats fed the experimental diets $(n=8)$

\begin{tabular}{|c|c|c|c|c|c|c|}
\hline \multirow[b]{2}{*}{ Item } & \multicolumn{4}{|c|}{$\operatorname{Diet}^{1}$} & \multirow[b]{2}{*}{ SEM } & \multirow[b]{2}{*}{$P$-value } \\
\hline & $\mathrm{AC}$ & $\mathrm{ACT}$ & $\mathrm{ACC}$ & $\mathrm{ACB}$ & & \\
\hline \multicolumn{7}{|l|}{ Methane emissions } \\
\hline $\mathrm{CH}_{4}, \mathrm{~L} / \mathrm{d}$ & $42.4^{\mathrm{c}}$ & $27.8^{\mathrm{a}}$ & $26.9^{\mathrm{a}}$ & $32.0^{\mathrm{b}}$ & 0.732 & $<0.001$ \\
\hline $\mathrm{CH}_{4}, \mathrm{~L} / \mathrm{kg}$ of $\mathrm{BW}$ & $2.77^{\mathrm{c}}$ & $1.81^{\mathrm{a}}$ & $1.71^{\mathrm{a}}$ & $2.03^{\mathrm{b}}$ & 0.095 & $<0.001$ \\
\hline $\mathrm{CH}_{4}, \mathrm{~L} / \mathrm{kg}$ of $\mathrm{DMI}$ & $28.2^{\mathrm{c}}$ & $17.4^{\mathrm{a}}$ & $17.2^{\mathrm{a}}$ & $19.7^{\mathrm{b}}$ & 0.558 & $<0.001$ \\
\hline $\mathrm{pH}$ & 6.94 & 7.00 & 6.93 & 6.91 & 0.036 & 0.39 \\
\hline $\mathrm{NH}_{3}-\mathrm{N}, \mathrm{mg} / 100 \mathrm{~mL}$ & $28.1^{\mathrm{b}}$ & $18.2^{\mathrm{a}}$ & $18.5^{\mathrm{a}}$ & $25.3^{\mathrm{b}}$ & 0.497 & 0.003 \\
\hline $\begin{array}{l}\text { Total VFA, mmol/L } \\
\mathrm{mmol} / 100 \mathrm{mmol}\end{array}$ & $149^{\mathrm{c}}$ & $109^{\mathrm{b}}$ & $161^{\mathrm{c}}$ & $85.6^{\mathrm{a}}$ & 2.62 & $<0.001$ \\
\hline Acetate & $67.6^{\mathrm{b}}$ & $65.2^{\mathrm{a}}$ & $65.9^{\mathrm{a}}$ & $65.5^{\mathrm{a}}$ & 0.440 & 0.03 \\
\hline Propionate & 12.8 & 13.3 & 15.2 & 12.5 & 0.297 & 0.09 \\
\hline Isobutyrate & $2.19^{\mathrm{a}}$ & $3.04^{\mathrm{b}}$ & $2.23^{\mathrm{a}}$ & $3.32^{\mathrm{b}}$ & 0.168 & 0.005 \\
\hline Butyrate & 13.9 & 14.2 & 13.0 & 13.8 & 0.276 & 0.49 \\
\hline Isovalerate & $2.43^{\mathrm{a}}$ & $3.04^{\mathrm{b}}$ & $2.71^{\mathrm{a}}$ & $3.61^{\mathrm{b}}$ & 0.125 & 0.001 \\
\hline Valerate & 1.07 & 1.22 & 0.94 & 1.26 & 0.034 & 0.07 \\
\hline Acetate:propionate & 5.35 & 5.01 & 4.48 & 5.44 & 0.152 & 0.27 \\
\hline \multicolumn{7}{|c|}{$\begin{array}{l}\text { Microbial densities, log gene } \\
\text { copies/g of wet weight }\end{array}$} \\
\hline Bacteria & 11.5 & 11.4 & 11.5 & 11.4 & 0.092 & 0.42 \\
\hline Methanogens & 9.04 & 8.83 & 8.91 & 8.86 & 0.095 & 0.44 \\
\hline
\end{tabular}

${ }^{\mathrm{a}-\mathrm{c}}$ Within a row, means not bearing a common superscript letter differ $(P<0.05)$.

${ }^{1} \mathrm{AC}=1,000 \mathrm{~g}$ of alfalfa hay and 1,000 $\mathrm{g}$ of concentrate; $\mathrm{ACT}=1,000 \mathrm{~g}$ of alfalfa hay, $650 \mathrm{~g}$ of concentrate, and $231.5 \pm 68.8 \mathrm{~g}$ (mean $\pm \mathrm{SD}$ ) of tomato feed block; $\mathrm{ACC}=1,000 \mathrm{~g}$ of alfalfa hay, $650 \mathrm{~g}$ of concentrate, and $239 \pm 58.9 \mathrm{~g}$ (mean $\pm \mathrm{SD}$ ) of cucumber feed block; $\mathrm{ACB}=1,000 \mathrm{~g}$ of alfalfa hay, $650 \mathrm{~g}$ of concentrate, and 223 $\pm 87.6 \mathrm{~g}$ (mean $\pm \mathrm{SD})$ of barley feed block (fresh-matter basis).

${ }^{2}$ Logarithm of copies of $16 \mathrm{~S}$ rRNA and methyl coenzyme M reductase A genes used for quantification of bacteria and methanogens, respectively. The value represents the density of bacteria or methanogens.

\section{Ruminal Fermentation and Methane Production}

The average $\mathrm{pH}$ in the rumen of goats was not different $(P=0.39)$ among diets (Table 6$)$. Although $\mathrm{pH}$ was not affected by diet, VFA concentration in the rumen of goats fed AC or ACC was higher $(P<0.001)$ than that in goats fed ACT and ACB. The lack of correlation between $\mathrm{pH}$ values and VFA concentration agrees with observations of other authors (Busquet et al., 2005; Cantalapiedra-Hijar et al., 2009) and may be due to the contamination of rumen samples with saliva. Total VFA concentration in the rumen of goats was higher than values previously reported for MurcianoGranadina goats fed diets based on alfalfa hay (MolinaAlcaide et al., 2000). Additionally, goats supplemented with barley-based FB had lower rumen VFA concentration than the other diets. The molar proportion of acetate was higher $(P=0.03)$ for AC compared with $\mathrm{ACT}, \mathrm{ACC}$, and $\mathrm{ACB}$, but the acetate:propionate ratio was unaffected by diets. Isobutyrate and isovalerate molar proportions were reduced $(P=0.005$ and 0.001 , respectively) in goats fed $\mathrm{AC}$ and $\mathrm{ACC}$. Goats fed diets including FB containing tomato and cucumber had lower ruminal concentration of $\mathrm{NH}_{3}-\mathrm{N}(P=0.003)$ than animals receiving $\mathrm{AC}$ and $\mathrm{ACB}$. Our ruminal $\mathrm{NH}_{3}-\mathrm{N}$ values were within the range of those found in previous studies with goats fed similar diets (Molina-Alcaide et al., 2000). However, rumen content was sampled only once during each period and just after feeding, which may limit the value and interpretation of these results.

Interest is increasing in the study of antimethanogenic compounds to reduce livestock greenhouse gas emissions and improve the efficiency of energy utilization in ruminants. Methane reduction may be a result of different processes: decreasing OM fermentation in the rumen and increasing OM fermentation in the intestine; diverting hydrogen away from $\mathrm{CH}_{4}$ production; and inhibition of microbial activity or optimization of rumen fermentation, decreasing methane emission per unit of OM digested (Ben Salem, 2010; Martín et al., 2010). No information is available regarding the effect of vegetal byproducts and waste-based FB on methane emissions. In our experiment, the inclusion of $\mathrm{FB}$ in goat diets had an antimethanogenic effect. Thus, compared with the control diet, methane emissions expressed per kilogram of BW or DMI were lowered by about $39 \%$ with diets including tomato and cucumber $\mathrm{FB}$ and $29 \%(P$ $<0.001)$ in animals receiving ACB. Whereas the reduction in methane emissions found in goats fed ACC was accompanied by increased $(P=0.09)$ propionate molar 
proportions, the utilization of tomato and barley FB did not promote any changes in propionate proportions. However, a reduction in methane emissions without increased propionate molar proportion could be possible when other metabolic pathways act as hydrogen sinks. Differences found among ACT, ACC, and ACB regarding methane emissions are difficult to explain, and may rely upon differences in block chemical compositions. Therefore, FB including tomato or cucumber waste fruits may also have an added value derived from the presence of plant secondary compounds, which could act as natural safe antimethanogenic additives, alternative to the chemical additives, as suggested by Patra and Saxena (2010). Similar values for methane emissions (L/kg of DMI) using respiration chambers were also found in goats treated with bromochloromethane with proved antimethanogenic activity (Abecia et al., 2012). An additional advantage of the strategy involving the replacement of $35 \%$ of concentrate with FB including tomato or cucumber fruits is the lack of effect on DMI, which has been shown to be decreased with some antimethanogenic strategies (Beauchemin et al., 2008). In addition, the abundances of total bacteria and methanogens were not affected by diet, suggesting the absence of any relationship between the reduction in methane emissions and the abundance of methanogens (Machmüller et al., 2003). It has been hypothesized that, rather than the species numbers, the species composition of the archaea community drives the synthesis of methane in the rumen (Morgavi et al., 2010), but it remains unknown which genera or species of archaea are most involved in ruminal methane production.

Thus, the reduction of methane emissions without changes in nutrient digestibility with small modifications in rumen fermentation patterns, promoted by partial replacement of concentrate with tomato and cucumber FB, suggests that tomato and cucumber FB could be a successful alternative to more expensive feed resources and to additives aiming to decrease methane emissions. In addition, the use of tomato and cucumber in dairy goats can also contribute to minimizing the negative environmental impact associated with those wastes and animal production.

\section{CONCLUSIONS}

The replacement of $35 \%$ of cereals-based concentrate in lactating goats with FB containing tomato and cucumber waste fruits reduced animal feeding cost and methane emissions and improved the quality of the FA profile in milk. Ruminal fermentation, nutrient digestibility, and milk yield were not compromised by replacement of concentrate with FB.

\section{ACKNOWLEDGMENTS}

Funding was provided by the Junta de Andalucía Excellence Projects Programme (projects P05-AGR-0408 and P07-RNM-02746). M. Romero-Huelva and E. Ramos-Morales gratefully acknowledge the receipt of a Junta para la Ampliación de Estudios (JAE) prescholarship and JAE postcontract from the Consejo Superior de Investigaciones Científicas (CSIC) of Madrid, Spain, respectively. Thanks to J. Fernandez and T. Garcia [Estación Experimental del Zaidín (CSIC), Granada, Spain] for technical assistance. Thanks to the Wastes Treatment Factory in Motril (Granada, Spain) for providing us with tomato and cucumber fruit wastes.

\section{REFERENCES}

Abbeddou, S., B. Rischkowsky, E. K. Richter, H. D. Hess, and M. Kreuzer. 2011. Modification of milk fatty acid composition by feeding forages and agro-industrial byproducts from dry areas to Awassi sheep. J. Dairy Sci. 94:4657-4668.

Abecia, L., P. G. Toral, A. I. Martin-García, G. Martínez, N. W. Tomkins, E. Molina-Alcaide, C. J. Newbold, and D. R. Yáñez-Ruiz. 2012. Effect of bromochloromethane on methane emission, rumen fermentation pattern, milk yield, and fatty acid profile in lactating dairy goats. J. Dairy Sci. 95:2027-2036.

Aguilera, J. F., C. Prieto, and J. Fonollá. 1990. Protein and energy metabolism of lactating Granadina goats. Br. J. Nutr. 63:165-175.

AOAC International. 2005. Official Methods of Analysis. 18th ed. AOAC International, Gaithersburg, MD.

Bach, A., S. Calsamiglia, and M. D. Stern. 2005. Nitrogen metabolism in the rumen. J. Dairy Sci. 88(E. Suppl.):E9-E21.

Balcells, J., J. A. Guada, J. M. Peiró, and D. S. Parker. 1992. Simultaneous determination of allantoin and oxypurines in biological fluids by high-performance liquid chromatography. J. Chromatogr. 575:153-157.

Beauchemin, K. A., M. Kreuzer, F. O'Mara, and T. A. McAllister. 2008. Nutritional management for enteric methane abatement: A review. Aust. J. Exp. Agric. 48:21-27.

Ben Salem, H. 2010. Nutritional management to improve sheep and goat performances in semiarid regions. R. Bras. Zootec. 39:337347

Ben Salem, H., and A. Nefzaoui. 2003. Feed blocks as alternative supplements for sheep and goats. Small Rumin. Res. 49:275-288.

Ben Salem, H., and I. A. Znaidi. 2008. Partial replacement of concentrate with tomato pulp and olive cake-based feed blocks as supplements for lambs fed wheat straw. Anim. Feed Sci. Technol. 147:206-222.

Bequette, B. J., F. R. C. Backwell, C. E. Kyle, A. G. Calder, V. Buchan, L. A. Crompton, J. France, and J. C. MacRae. 1999. Vascular sources of phenylalanine, tyrosine, lysine, and methionine for casein synthesis in lactating goats. J. Dairy Sci. 82:362-377.

Busquet, M., S. Calsamiglia, A. Ferret, P. W. Cardozo, and C. Kamel. 2005. Effects of cinnamaldehyde and garlic oil on rumen microbial fermentation in a dual flow continuous culture. J. Dairy Sci. $88: 2508-2516$.

Cantalapiedra-Hijar, G., D. R. Yáñez-Ruiz, A. I. Martín-García, and E. Molina-Alcaide. 2009. Effects of forage:concentrate ratio and forage type on apparent digestibility, ruminal fermentation, and microbial growth in goats. J. Anim. Sci. 87:622-631.

Cerrillo, M. A., J. R. Russell, and M. H. Crump. 1999. The effects of hay maturity and forage to concentrate ratio on digestion kinetics in goats. Small Rumin. Res. 32:51-60.

Christophersen, C. T. 2007. Grain and artificial stimulation of the rumen change the abundance and diversity of methanogens and 
their association with ciliates. PhD Thesis. University of Western Australia, Perth, Australia.

Denman, S. E., and C. S. McSweeney. 2006. Development of a realtime PCR assay for monitoring anaerobic fungal and cellulolytic bacterial populations within the rumen. FEMS Microbiol. Ecol. 58:572-582.

Devillard, E., F. M. McIntosh, C. J. Newbold, and R. J. Wallace. 2006. Rumen ciliate protozoa contain high concentrations of conjugated linoleic acids and vaccenic acid, yet do not hydrogenate linoleic acid or desaturate stearic acid. Br. J. Nutr. 96:697-704.

FAO (Food and Agriculture Organization of the United Nations). 2011. Crop prospects and food situation, No. 4, December 2011 Accessed Feb. 10, 2012. http://www.fao.org/giews/english/cpfs/ index.htm.

Isac, M. D., M. A. García, J. F. Aguilera, and E. Molina-Alcaide. 1994. A comparative study of nutrient digestibility, kinetics of digestion and passage and rumen fermentation pattern in goats and sheep offered medium quality forages at the maintenance level of feeding. Arch. Tierernahr. 46:37-50.

Kromhout, D., E. J. Giltay, and J. M. Geleijnse. 2010. n-3 Fatty acids and cardiovascular events after myocardial infarction. N. Engl. J. Med. 363:2015-2026.

Leiber, F., M. Kreuzer, D. Nigg, H. R. Wettstein, and M. R. Scheeder 2005. A study on the causes for the elevated n-3 fatty acids in cows' milk of alpine origin. Lipids 40:191-202.

Machmüller, A., C. R. Soliva, and M. Kreuzer. 2003. Methane-suppressing effect of myristic acid in sheep as affected by dietary calcium and forage proportion. Br. J. Nutr. 90:529-540.

Martín, C., D. P. Morgavi, and M. Doreau. 2010. Methane mitigation in ruminants: From microbe to the farm scale. Animal 4:351-365.

Modaresi, J., M. H. Fathi Nasri, L. Rashidi, O. Dayani, and E. Kebreab. 2011. Short communication: Effects of supplementation with pomegranate seed pulp on concentrations of conjugated linoleic acid and punicic acid in goat milk. J. Dairy Sci. 94:4075-4080.

Molina-Alcaide, E., A. I. García Martín, and J. F. Aguilera. 2000. A comparative study of nutrient digestibility, kinetics of degradation and passage and rumen fermentation pattern in goats and sheep offered good quality diets. Livest. Prod. Sci. 64:215-223.

Molina-Alcaide, E., E. Y. Morales-García, A. I. Martín-García, H. Ben Salem, A. Nefzaoui, and M. R. Sanz-Sampelayo. 2010. Effects of partial replacement of concentrate with feed blocks on nutrient utilization, microbial $\mathrm{N}$ flow, and milk yield and composition in goats. J. Dairy Sci. 93:2076-2087.

Morgavi, D. P., E. Forano, C. Martin, and C. J. Newbold. 2010. Microbial ecosystem and methanogenesis in ruminants. Animal 4:1024-1036

Mota, M., J. Balcells, N. Ozdemir Baber, S. Bölüktepe, and A. Belenguer. 2008. Modelling purine derivative excretion in dairy goats: Endogenous excretion and the relationship between duodenal input and urinary output. Animal 2:44-51.

Newbold, C. J., S. López, N. Nelson, J. O. Ouda, R. J. Wallace, and A. R. Moss. 2007. Propionate precursors and other metabolic intermediates as possible alternative electron acceptors to methanogenesis in ruminal fermentation in vitro. Br. J. Nutr. 94:27-35.
Patra, A. K., and J. Saxena. 2010. A new perspective on the use of plant secondary metabolites to inhibit methanogenesis in the rumen. Phytochemistry 71:1198-1222.

Pearson, D. M. 1976. Laboratory Techniques in Food Analysis. Butterworths, London, UK.

Perez-Maldonado, R. A., and B. W. Norton. 1996. Digestion of ${ }^{14} \mathrm{C}-$ labelled condensed tannins from Desmodium intortum in sheep and goats. Br. J. Nutr. 76:501-513.

Recio, I., M. L. Pérez-Rodríguez, L. Amigo, and M. Ramos. 1997. Study of the polymorphism of caprine milk caseins by capillary electrophoresis. J. Dairy Res. 64:515-523.

Romano, R., F. Masucci, A. Giordano, S. S. Musso, D. Naviglio, and A. Santini. 2010. Effect of tomato by-products in the diet of Comisana sheep on composition and conjugated linoleic acid content of milk fat. Int. Dairy J. 20:858-862.

Sansoucy, R. 1986. The Sahel: Manufacture and molasses-urea blocks. World Anim. Rev. 57:40-48.

Sanz Sampelayo, M. R., J. J. Martín Alonso, D. Morón, L. Pérez, and J. Boza. 2000. Production of healthier goat milk. Use of a concentrate supplemented with a "protected" fat rich in PUFA. J. Physiol. Biochem. 56:231-236.

Shingfield, K. J., S. Ahvenjärvi, V. Toivonen, A. Ärölä, K. V. V. Nurmela, P. Huhtanen, and J. M. Griinari. 2003. Effect of dietary fish oil on biohydrogenation of fatty acids and milk fatty acid content in cows. Anim. Sci. 77:165-179.

Simopoulos, A. P. 2002. The importance of the ratio of omega-6/omega-3 essential fatty acids. Biomed. Pharmacother. 56:365-379.

Tsiplakou, E., and G. Zervas. 2008. Comparative study between sheep and goats on rumenic acid and vaccenic acid in milk fat under the same dietary treatments. Livest. Sci. 119:87-94.

Van Soest, P. J., J. B. Robertson, and B. A. Lewis. 1991. Methods for dietary fiber, neutral detergent fiber, and nonstarch polysaccharides in relation to animal nutrition. J. Dairy Sci. 74:3583-3597.

Vasta, V., A. Nudda, A. Cannas, M. Lanza, and A. Priolo. 2008. Alternative feed resources and their effects on the quality of meat and milk from small ruminants. Anim. Feed Sci. Technol. 147:223246.

Ventura, M. R., M. C. Pieltain, and J. I. R. Castanon. 2009. Evaluation of tomato crop by-products as feed for goats. Anim. Feed Sci. Technol. 154:271-275.

Wąsowska, I., M. Maia, K. M. Niedźwiedzka, M. Czauderna, J. M. C. Ramalho Ribeiro, E. Devillard, K. J. Shingfield, and R. J. Wallace. 2006. Influence of fish oil on ruminal biohydrogenation of $\mathrm{C} 18$ unsaturated fatty acids. Br. J. Nutr. 95:1199-1211.

Weatherburn, M. W. 1967. Phenol-hypochlorite reaction for determination of ammonia. Anal. Chem. 39:971-974.

Wright, A.-D. G., K. S. Northwood, and N. E. Obispo. 2009. Rumen-like methanogens identified from the crop of the folivorous South American bird, the hoatzin (Opisthocomus hoazin). ISME J. 3:1120-1126.

Yu, Z., and M. Morrison. 2004. Improved extraction of PCR-quality community DNA from digesta and fecal samples. Biotechniques $36: 808-812$. 